\title{
Behavior Guidance in Pediatric Dentistry - A Review
}

Majd Ibraheem*

Department of Pediatric Dentistry, Tishreen University, Lattakia, Syria.

\section{Abstract}

There are many behavior guidance techniques used in pediatric dentistry which can be used separately or combined, the main purpose of these techniques is to help the pediatric patients to accept the dental procedures, and to feel comfortable and satisfied about it. Although some of these techniques seem intuitive and may be used offhandedly by untrained dentists, consciously practicing them can help develop skills with children.

The dentist should formulate a behavior guidance plan for the total patient's comfort which compatibles with child personality and treatment plan.

The review concentrates on the behavior Guidance techniques, classifications, alternatives, and mechanisms.

\section{Introduction}

For some pediatric patients, dental treatment represents an unwanted event, and generally involves pain, fear, and anxiety [1], The techniques that guide behavior and reduce anxiety are very important for achieving the safe and effective treatment [2].

It is important for dentist to gain familiarity with his pediatric patient before treatment, which helps improving the child's experience. At least the dentist should ask about previous dental visits and the child's behavior at these visits. Rejection behavior and dental anxiety in the dental situation are significantly associated with the previous traumatic experiences and previous extraction $[3,4]$.

The behavior guidance is not a process involves only the dentist and the child, but it is systematic techniques in which the success depends on the dentist's ability to communicate with parents, child, and staff [5].

The dentist needs experience and training to choose the most appropriate technique for each child, according to his fears, personality and previous experiences, there are several questionnaires and surveys can helpgathering information about the child fear, anxiety, and temperament, but their clinical efficacy is still undefined.
A simple facial image scale has shown a validity in determining the dental anxiety [6]. The dental subset of the Children's Fear Survey Schedule has been used to determine the younger children's fears [7], and the Emotionality, Activity, and Sociability (EAS) Temperament Survey can define the temperament types that more prone to distress, particularly shyness [8]. Also watching child actions in the waiting room, especially his/her interact with parents, and respond to dental personnel can give extra information $[9,10]$.

The dentist's appearance should be neat, and no need to change the traditional white coat, because some studies showed that parents and children prefer it $[11,12]$, In addition, personal protective equipments had not been shown to increase children fear [13].

Most behavior guidance techniques have been listed in AAPD guidelines, and classified to basic and advanced techniques [2]. According to the AAPD recommendations the communication techniques don't require any specific consent, while any others require informed consent from parents or legal guardian before treatment beginning, which must be documented in the patient's record [2].

\section{Basic Behavior Guidance Techniques}

\section{Communication and Communicative Guidance}

The communication represents the foundation for entire basic

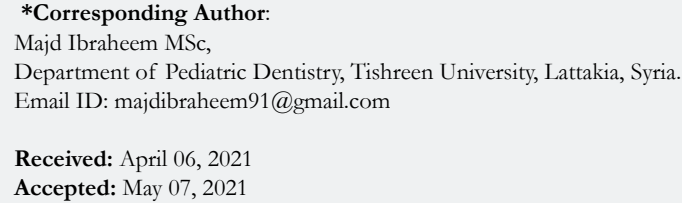


behavior guidance techniques, all requests and commands have to be literal, direct, brief, and suitable for the child's level of comprehension [14], the dentist must avoid "Don't" commands, especially for toddlers and preschoolers because of lack of development in language processing skills. These commands may motivate unwanted, negative, non-cooperative behavior [15].

To achieve successful cooperation, the dentist shouldfind open lines of communication with the child, keepingthem all over the appointment [16], the directive communicating with children requires relaxed tone of voice, without any extended explanations which are ineffective [17].

\section{Tell-Show-Do(TSD)}

(TSD) is one of the most popular behavior management techniques [16], the patient in which is introduced to the dental office as a nonthreatening environment in a way that can be understood. First the child is told about the procedure and instrument in a child-friendly manner. For example, the Curing light may be called a "Flashlight." Next the child is allowed to see, touch, or smell the material or instrument, Finally, the child Undergoes the procedure. This technique is recommended with children capable of communication $[18,19]$.

\section{Positive Reinforcement}

Positive reinforcement is a way to promote positive behavior by rewards, and it is universally accepted. Social positive reinforcement is most effective when it concentrates on the cooperative behavior, such as " Thank you for sitting so still and opening your mouth so wide " Like this focused comment would motivate the child to continue the wanted behavior [16].

\section{Nonverbal Behavior Guidance}

It is the technique that depends on reinforcement and guidance of behavior by appropriate contact, facial expressions, body language, and posture [2]. The attentive practitioner can use this communication form to help shape ideal behavior in the child [22]. Eye contact, smiling, and an upbeat tone of voice conveys toa child that the dentist is confident that the child will enjoythe visit. A practitioner must remember that personal protectiveequipment (PPE) like the medical mask and eye protection may hide the dentist facial expressions and should take off (PPE) when welcoming the child. Children between 7 and 10 years who were patted on the shoulder showed less fidgeting behavior than the children who didn't receive this touch; they also reported more acceptance of the visit [24]. Very young children may misinterpret nonverbal cues, a study reported that the 3 years patients were significantly less accurate than (6-9) year patients at correctly identifying emotions relatedto facial expressions, in addition, 3 years patients were more likely to confuse happy and angry for sad [25].

\section{Distraction}

Among all the behavior guidance techniques in pediatric dentistry, distraction has the most researchthat supports its effectiveness. A Cochrane review of psychological interventions for needle-related procedural pain in children found strong evidence supporting distraction [26] Conversation is the basic form of distraction, and physical distraction can be useful like asking a child to rotate his feet during the injection $[16,22]$. The dentist may enlist the assistants or parents in distracting the patient, either by storytelling or playing a game, there is a study used posters and stories by the auxiliary and found decreases indisruptive and anxious behavior [27]. There are studies tested the audio visual devices such as wraparound eyewear and reports that are effective in promoting cooperative behavior [28-30], may success of these types of devices due to the ability block out upsetting stimuli.

\section{Voice Control}

Voice control is a means that the dentist in which modulates voice tone and/or volume to gain the patient's attention and cooperation. In voice control, commands should be firm with facial expression mirroring the message [31]. Although voice control can be effective at normal volume, (Greenbaum et al) found that the loud voice was most effective at reducing disruptiveness [32].

\section{Positive Pre visit Imagery}

A new technique added to the AAPD guidelines [2]. This technique involves showing children positive images of dentistry before dental visit [33]. Two researches have shown that exposing children to positive images about dentistry significantly minimized anxiety compared to neutral pictures [33,34] while another study find no significant difference [35].

\section{Direct Observation}

Direct observation depends on modeling concept and social learning by allowing the child to observe a cooperative child patient undergoing dental treatment [2]. Modeling is better to use with children who had no previous dental experiment [36]. The observation could be live or by video display, Melamed et al. found significantly less negative behavior when children watched a video of interested child during dental appointment and is rewarded $[37,38]$.

\section{Parental Presence/Absence}

The child's desire for parental presence may become a significant factor forbehavior management. For young children aged 41-49 months it is not recommended to separate them from their parents $[39,40]$. According to Kamp et al.the separation got rid of several behavioral problems, because excluding the parent allows the dentist to develop a rapport with the child without any interference [41]. During initial visits child should not be separated from parents as their presence may help in the prediction of a future child's behavior [42].

Current trends appear to emerge in the direction of the growing desire of pediatric dentists to permit parents' presence for all their child visits [43].

\section{Memory Restructuring}

Memory restructuring has been suggested as a technique to prevent fear and anxiety after an aversive dental experience [44]. This techniquehas four specific elements: visual reminder,verbalization, concrete examples, and the sense ofaccomplishment [16, 44]. Pickrell et al. in a study of 6-9 years patients, found this technique improved child behavior and changed negative memories [44]. 


\section{Nitrous Oxide Sedation}

$\left(\mathrm{N}_{2} \mathrm{O} / \mathrm{O}_{2}\right)$ sedation is inhaledpharmacologicaltechnique improves child behavior that have mild to moderately anxious It is important to use N2O/O2 accompanying with communicative behavior guidance techniques such as TSD, positive reinforcement, and distraction [45]. Nelson et al. found that children with high effortful control weremore successfully sedated with nitrous oxide [46], usually $\mathrm{N}_{2} \mathrm{O} / \mathrm{O}_{2}$ is easily accepted by parents [47].

\section{Alternative Communicative Techniques}

\section{Escape}

Typically escape is the cessation of action in the mouth cavity, without getting up from the chair, there are two types of escape; contingent and noncontingent [16]. The most used form is "If you can stay still till I count to 10, we can take a break. Allen et al. have demonstrated success with this procedure in preschool-aged disruptive children $[48,49]$.

\section{Desensitization}

Desensitization is exposure to fear-invoking stimuli in a progressive manner, starting withthe least disturbing [50]. Patients' selfidentify their fears, are taught relaxation techniques, and are gradually exposed to the situations that they identify, this technique is effective long term in reducing dental fear $[51,52]$.

\section{Deferred Treatment}

An often overlooked alternative is to simply defer treatment. When a patient's behavior represents an obstacle to effective and safe care, with no emergency needs, deferring appointment would be valid alternative [2].

\section{Advanced Behavior Guidance Techniques}

Sometimes the basic behavior guidance techniques are not enough to achieve perfect, safe dental care. This may be due to the young age of the child, special needs, excessive defiance, or extreme fear. In these cases it is necessary to engage the parents to discuss the possible alternatives of advanced behavior guidance so that they can make an informed decision.

\section{Protective Stabilization}

Protective Stabilization is defined as "any manual method, physical or mechanical device, material, or equipment that immobilizes or reduces the ability of a patient to move his / her arms, legs, body, or head freely"[53]. It is used to avoid injuries during dental procedures, and classified to active and passive [54]. In the active type, the parent, dentist, or assistant helps stabilize the child patient, the active stabilizationis typically used for short periods especiallywhen the unexpected disruptive behavior occurs [55]. The passive stabilization depends on using a device to restrict patient movement, such as (Papoose ${ }^{\circledR}$ board Posey straps ${ }^{\circledR}$, Velcro ${ }^{\circledR}$ straps, seat belts).All advanced techniques require the clinical training, specific documented informed consent [54].

\section{Sedation and General Anesthesia}

Sedation is a pharmacologic behavior management technique, there are three levels of sedation; Minimal Sedation is a druginduced state during which patients respond normally to verbal commands with no affection on ventilatory and cardiovascular functions, Moderate Sedation is partial depression of consciousness and patients respond purposefully to verbal commands, while Deep Sedation is a controlled state of unconsciousness in which the patient is not aroused easily, with a degree of protective reflexes absence [56].

The routes of sedation administration are inhalational (Nitrous Oxide), enteral (oral or rectal), and parenteral (intramuscular, subcutaneous, submucosal, intranasal, or intravenous) [56].

In some cases, dental treatment under general anesthesia (GA) is the most practical and cost-effective type of treatment [57]. A certain patients who can't tolerate traditional dental treatment can only be treated under GA, such as very young children, or who suffering physical, mental, cognitive or emotional immaturity or disability or those with extreme anxiety who need extensive rehabilitation are treated using GA [58].

\section{Conclusion}

We can summarize the dentistry requirements for children by stating that "the task of dentists is the same as it was a generation ago: to provide perfect dental care for children whose behavior may range from cooperative to hostile to defiant."

Behavior Guidance is the art of recognizing the complexities of children's and dentists' temperaments, parents' attitudes, and varying treatment needs to establish an optimal treatment plan to best address the child's needs.

\section{References}

[1]. Nathan JE. Behavioral management strategies for young pediatric dental patients with disabilities. Journal of Dentistry for Children. 2001 Mar 1;68(2):89-101.

[2]. American Academy of Pediatric Dentistry .Guideline on behavior guidance for thepediatric dental patient. Pediatr Dent 2010-2011;32: 147 - 55.

[3]. Tickle M, Jones C, Buchannan K, Milsom KM, Blinkhorn AS, Humphris GM. A prospective study of dental anxiety in a cohort of children followed from 5 to 9 years of age. Int J Paediatr Dent. 2009 Jul;19(4):225-32. Pubmed PMID: 19486376.

[4]. Corkey B, Freeman R. Predictors of dental anxiety in six-year-old children: findings from a pilot study. ASDC J Dent Child. 1994 JulAug;61(4):267-71. Pubmed PMID: 7989630.

[5]. Torriani DD, Ferro RL, Bonow ML, Santos IS, Matijasevich A, Barros AJ, et al. Dental caries is associated with dental fear in childhood: findings from a birth cohort study. Caries Res. 2014;48(4):263-70. Pubmed PMID: 24503491

[6]. Buchanan H, Niven N. Validation of a Facial Image Scale to assess child dental anxiety. Int J Paediatr Dent. 2002 Jan;12(1):47-52. Pubmed PMID: 11853248.

[7]. Cuthbert MI, Melamed BG. A screening device: children at risk for dental fears and management problems. ASDC J Dent Child. 1982 NovDec;49(6):432-6. Pubmed PMID: 6960031.

[8]. Quinonez R, Santos RG, Boyar R, Cross H. Temperament and trait anxiety as predictors of child behavior prior to general anesthesia for dental surgery. Pediatr Dent. 1997 Sep-Oct;19(6):427-31. Pubmed PMID: 9348611.

[9]. McTigue DJ, Pinkham J. Association between children's dental behavior and play behavior. ASDC J Dent Child. 1978 May-Jun;45(3):218-22. Pubmed PMID: 277446.

[10]. Pinkham JR. Observation and interpretation of the child dental patient's 
behavior. Pediatric dentistry. 1979 Mar;1(1):21-6.

[11]. Mistry D, Tahmassebi JF. Children's and parents' attitudes towards dentists' attire. European Archives of Paediatric Dentistry. 2009 Dec;10(4):237-40.

[12]. Panda A, Garg I, Bhobe AP. Children's perspective on the dentist's attire. Int J Paediatr Dent. 2014 Mar;24(2):98-103. Pubmed PMID: 23600841.

[13]. Davis R, McKibben DH, Nazif MM, Bartko J. Child reaction to protective garb at the first dental visit. Pediatr Dent. 1993 Mar-Apr;15(2):86-7. Pubmed PMID: 8327364

[14]. Blum NJ, Williams GE, Friman PC, Christophersen ER. Disciplining young children: the role of verbal instructions and reasoning. Pediatrics. 1995 Aug;96(2 Pt 1):336-41. Pubmed PMID: 7630695.

[15]. Jones RN, Sloane HN, Roberts MW. Limitations of "don't instructional control. Behavior Therapy. 1992 Dec 1;23(1):131-40.

[16]. Nowak A, Christensen JR, Mabry TR, Townsend JA, Wells MH, editors. Pediatric dentistry-E-book: Infancy through adolescence. Elsevier Health Sciences; 2018 May 10.

[17]. Harper DC, D'Alessandro DM. The child's voice: understanding the contexts of children and families today. Pediatr Dent. 2004 MarApr;26(2):114-20. Pubmed PMID: 15132272.

[18]. Lawrence SM, McTigue DJ, Wilson S, Odom JG, Waggoner WF, Fields Jr HW. Parental attitudes toward behavior management techniques used in pediatric dentistry. Pediatr Dent. 1991 May 1;13(3):151-5.

[19]. Scott S, García-Godoy F. Attitudes of Hispanic parents toward behavior management techniques. ASDC J Dent Child. 1998 Mar-Apr;65(2):128-31. Pubmed PMID: 9617454

[20]. Eaton JJ, McTigue DJ, Fields HW Jr, Beck M. Attitudes of contemporary parents toward behavior management techniques used in pediatric dentistry. Pediatr Dent. 2005 Mar-Apr;27(2):107-13. Pubmed PMID: 15926287.

[21]. Davies EB, Buchanan H. An exploratory study investigating children's perceptions of dental behavioural management techniques. Int J Paediatr Dent. 2013 Jul;23(4):297-309. Pubmed PMID: 23163933.

[22]. Hamzah HS, Gao X, Yung Yiu CK, McGrath C, King NM. Managing dental fear and anxiety in pediatric patients: A qualitative study from the public's perspective. Pediatr Dent. 2014 Jan-Feb;36(1):29-33. Pubmed PMID: 24717706.

[23]. Peretz B, Kharouba J, Blumer S. Pattern of parental acceptance of management techniques used in pediatric dentistry. J Clin Pediatr Dent. 2013 Fall;38(1):27-30. Pubmed PMID: 24579279

[24]. Greenbaum PE, Lumley MA, Turner C, Melamed BG. Dentist's reassuring touch: effects on children's behavior. Pediatr Dent. 1993 JanFeb;15(1):20-4. Pubmed PMID: 8233987.

[25]. Wilson S, Flood T, Kramer N, McTigue DJ, Steinberg B. A study of facially expressed emotions as a function of age, exposure time, and sex in children. Pediatr Dent. 1990 Feb;12(1):28-32. Pubmed PMID: 2399179.

[26]. Uman LS, Birnie KA, Noel M, Parker JA, Chambers CT, McGrath PJ, et al. Psychological interventions for needle-related procedural pain and distress in children and adolescents. Cochrane Database Syst Rev. 2013 Oct 10;(10):CD005179. Pubmed PMID: 24108531.

[27]. Stark LJ, Allen KD, Hurst M, Nash DA, Rigney B, Stokes TF. Distraction: its utilization and efficacy with children undergoing dental treatment. J Appl Behav Anal. 1989 Fall;22(3):297-307. Pubmed PMID: 2793636.

[28]. Hoge MA, Howard MR, Wallace DP, Allen KD. Use of video eyewear to manage distress in children during restorative dental treatment. Pediatr Dent. 2012 Sep-Oct;34(5):378-82. Pubmed PMID: 23211912.

[29]. Ram D, Shapira J, Holan G, Magora F, Cohen S, Davidovich E. Audiovisual video eyeglass distraction during dental treatment in children. Quintessence Int. 2010 Sep;41(8):673-9. Pubmed PMID: 20657857.

[30]. El-Sharkawi HF, El-Housseiny AA, Aly AM. Effectiveness of new distraction technique on pain associated with injection of local anesthesia for children. Pediatr Dent. 2012 Mar-Apr;34(2):e35-8. Pubmed PMID: 22583875.

[31]. Pinkham JR, Paterson JR. Voice control: an old technique reexamined. ASDC journal of dentistry for children. 1985 May 1;52(3):199-202.

[32]. Greenbaum PE, Turner C, Cook EW, Melamed BG. Dentists' voice control: Effects on children's disruptive and affective behavior. Health Psychology. 1990;9(5):546.

[33]. Fox C, Newton JT. A controlled trial of the impact of exposure to positive images of dentistry on anticipatory dental fear in children. Community Dent Oral Epidemiol. 2006 Dec;34(6):455-9. Pubmed PMID: 17092274.

[34]. Gangwal RR, Rameshchandra Badjatia S, Harish Dave B. Effect of Exposure to Positive Images of Dentistry on Dental Anxiety among 7 to 12 Years Old Children. Int J Clin Pediatr Dent. 2014 Sep-Dec;7(3):176-9. Pubmed

\section{PMID: 25709297.}

[35]. Ramos-Jorge ML, Ramos-Jorge J, Vieira de Andrade RG, Marques LS. Impact of exposure to positive images on dental anxiety among children: a controlled trial. Eur Arch Paediatr Dent. 2011 Aug;12(4):195-9. Pubmed PMID: 21806903.

[36]. Greenbaum PE, Melamed BG. Pretreatment modeling. A technique for reducing children's fear in the dental operatory. Dent Clin North Am. 1988 Oct;32(4):693-704. Pubmed PMID: 3053265.

[37]. Melamed BG, Weinstein D, Katin-Borland M, Hawes R. Reduction of fearrelated dental management problems with use of filmed modeling. J Am Dent Assoc. 1975 Apr;90(4):822-6. Pubmed PMID: 123932.

[38]. Melamed BG, Hawes RR, Heiby E, Glick J. Use of filmed modeling to reduce uncooperative behavior of children during dental treatment. J Dent Res. 1975 Jul-Aug;54(4):797-801. Pubmed PMID: 1057562.

[39]. FRANKL SN. Should the parent remain with the child in the dental operatory?. J. Dent. Child.. 1962;29:150-63.

[40]. Acharya S, Jena P, Acharya S. Parental Presence in Dental Operatory as a Behaviour Management Tool on Children in Bhubaneswar, Odisha, India. Pesquisa Brasileira em Odontopediatria e Clínica Integrada. 2019;19.

[41]. Kamp AA. Parent child separation during dental care: a survey of parent's preference. Pediatr Dent. 1992 Jul-Aug;14(4):231-5. Pubmed PMID: 1303521

[42]. Olsen NH. The first appointment--a mutual evaluation session. J Dent Child. 1965;32(4):208-11. Pubmed PMID: 4220440.

[43]. Suprabha BS, Rao A. Role of parent in behavior guidance of children in dental operatory: Current trends. International Journal of Advanced Research. 2015;3(1):466-70.

[44]. Pickrell JE, Heima M, Weinstein P, Coolidge T, Coldwell SE, Skaret E, et al. Using memory restructuring strategy to enhance dental behaviour. Int J Paediatr Dent. 2007 Nov;17(6):439-48. Pubmed PMID: 17935597.

[45]. Veerkamp JS, Gruythuysen RJ, Hoogstraten J, van Amerongen WE. Anxiety reduction with nitrous oxide: a permanent solution? ASDC J Dent Child. 1995 Jan-Feb;62(1):44-8. Pubmed PMID: 7775683.

[46]. Nelson TM, Griffith TM, Lane KJ, Thikkurissy S, Scott JM. Temperament as a Predictor of Nitrous Oxide Inhalation Sedation Success. Anesth Prog. 2017 Spring;64(1):17-21. Pubmed PMID: 28128664.

[47]. Eaton JJ, McTigue DJ, Fields HW Jr, Beck M. Attitudes of contemporary parents toward behavior management techniques used in pediatric dentistry. Pediatr Dent. 2005 Mar-Apr;27(2):107-13. Pubmed PMID: 15926287.

[48]. Allen KD, Loiben T, Allen SJ, Stanley RT. Dentist-implemented contingent escape for management of disruptive child behavior. J Appl Behav Anal. 1992 Fall;25(3):629-36. Pubmed PMID: 1429316

[49]. Allen KD, Stokes TF. Use of escape and reward in the management of young children during dental treatment. J Appl Behav Anal. 1987 Winter;20(4):381-90. Pubmed PMID: 3429360.

[50]. WOLPE J. Reciprocal inhibition as the main basis of psychotherapeutic effects. AMA Arch Neurol Psychiatry. 1954 Aug;72(2):205-26. Pubmed PMID: 13180056.

[51]. Hakeberg M, Berggren U, Carlsson SG. A 10-year follow-up of patients treated for dental fear. Scand J Dent Res. 1990 Feb;98(1):53-9. Pubmed PMID: 1970194.

[52]. Coldwell SE, Getz T, Milgrom P, Prall CW, Spadafora A, Ramsay DS. CARL: a LabVIEW 3 computer program for conducting exposure therapy for the treatment of dental injection fear. Behaviour Research and Therapy. 1998 Apr 1;36(4):429-41.

[53]. Office of the Federal Register. Code of Federal Regulations. 42Public Health, 482.13. 2010

[54]. Guideline on Protective Stabilization for Pediatric Dental Patients. Pediatr Dent. 2016 Oct;38(6):199-203. Pubmed PMID: 27931460.

[55]. Spreat S, Lipinski D, Hill J, Halpin ME. Safety indices associated with the use of contingent restraint procedures. Appl Res Ment Retard. 1986;7(4):475-81. Pubmed PMID: 3800372.

[56]. Casamassimo PS. Pediatric dentistry: infancy through adolescence. Elsevier/ Saunders,; 2013.

[57]. Thikkurissy S, Crawford B, Groner J, Stewart R, Smiley MK. Effect of passive smoke exposure on general anesthesia for pediatric dental patients. Anesth Prog. 2012 Winter;59(4):143-6. Pubmed PMID: 23241036.

[58]. Ramazani N. Different Aspects of General Anesthesia in Pediatric Dentistry: A Review. Iran J Pediatr. 2016 Mar 5;26(2):e2613. Pubmed PMID 27307962. 